\title{
Study on Factors Delaying Lead Time in the Apparel Supply Chain Management: A Case Study on the Order of Execution Strategies of a Garment Factory in Bangladesh
}

\author{
Sabbir Ahmed Abir, \\ BGMEA University of Fashion \& Technology (BUFT)
}

Doi:10.19044/esj.2020.v16n3p244ＵRL:http://dx.doi.org/10.19044/esj.2020.v16n3p244

\begin{abstract}
Bangladesh garments industry is searching out for ways to reduce lead time during apparel order execution for many rational reasons among which buyer's satisfaction, achieving target shipment date, and building a stable sector are some mentionable motives. One way to abridge lead time is to identify and analyze the root causes to delay in the approval period. Lead time refers to the time in between receiving order and dispatching to buyer. A number of reasons are responsible for delayed lead time. For instance, factory capacity, poor work force, raw material supply, wrong understanding about product details, miscommunication among inter-departments, longer approval period, lack of proper planning, submission of poor quality items, re-work, and re-submissions, etc. Among all of these reasons listed, longer approval period, submission of poor quality materials, re-work, and raw material supply hold the utmost importance. This study was based on the investigation of the abovementioned factors that reasonably delay lead time. A compliant garments industry was selected that receives order from a renowned buying office located in Germany. The ultimate customer of that buying office is also located in Germany who operates a number of lucrative stores in several countries in the globe. The study was carried out for an order with a quantity of 73,890 pcs. Results evinced that, due to longer approval period for submitted material (i.e., metal button, first styling sample), up to 24 days' extension are required to extend for order execution. Besides, submission of poor quality sample and re-work (i.e., print strike-off, size set, and lab dip sample) lead up to 22 days extension. The raw material (i.e., fabric and trims) in-house period also delayed the total period. For the total order shipment, it required 45 days' extension with respect to the given shipment date.
\end{abstract}

Keywords: Cold Pigment Dye, Lead Time, Supply Chain Management, SMV 


\section{Introduction}

The constantly changing styles of fast-fashion apparel and the growing diversification of consumer preferences create a keen competitive environment in the apparel retailing industry. For this reason, it is becoming increasingly competitive based on customer satisfaction (Gaskill, 1992; Gaither \& Fraizier, 1999). The apparel industry stands out as one of the most globalized industries in the world. It is also a supply-driven commodity chain led by a combination of retailers, contractors, subcontractors, merchandisers, buyers, and suppliers. Each plays an important role in a network of supply chains which spans from fibers to yarn, to fabrics, to accessories, to garments, to trading, and to marketing. The peculiar characteristics of apparel supply chain are short product life cycle, high volatility, low predictability, and high impulsive purchasing. These factors exert high pressure on apparel retailers to manage their supply chains. Moreover, in today's competitive environment where markets are becoming more international, dynamic, and customer-driven, customers are demanding more variety, better quality and service, including reliability and faster delivery. This is why this sector needs to maintain a long supply chain (backward and forward). Organizations that have focused on cycle time as a productivity measure can reduce delivery time and improve quality, thereby offering higher customer satisfaction. Cycle time or lead time is the time when a customer releases an order until the time they receive the finished product. Before 1980, customers tolerated long lead times which enabled producers to minimize product cost by using economical batch sizes. Later, when customers began to demand shorter lead times, competitors were able to deliver within a shorter period. This gave rise to a new problem and companies began to seek and implement changes to keep up with the rising competition. As soon as manufacturers focused on processes, they found some waste associated with changeovers, quality defects, process control, factory layout, and machine down time. Hence, they tried to find ways to eliminate waste. By eliminating the non-value adding activities from the processes and streamlining the information flow, significant optimization results can be realized (Harrington, 1996). The apparel industry is also an important business sector in Bangladesh. For this reason, companies operating within this sector must then be able to apply business strategies that would help them to sustain the growth of the clothing sector. This means that by modifying some of the existing business procedures such as supply chain management systems, continuous progress in the industry plus significant improvement can be achieved. This in turn may enable the formulation of better supply chain management practices that would contribute to the continuous progress of this industry. The development of the supply chain management in the business sector of Bangladesh can also likely strengthen its connection 
with the international market. Aside from these benefits, the apparel industry is able to achieve quick response through efficient supply chain management practices. Order time management is one of the big issues for Bangladeshi ready-made garment industry. Foreign buyers are likely to need short lead time. In BD, the lead time for apparel export varies between 90-120 days, whereas the time for Sri Lanka is about 19-45 days, China 40-50 days, and India around 50-70 days for similar products. Due to the growing intensity of competition in both local and global business arenas, several companies and service providers realized the need to develop more strategic approaches for managing the supply chain. Therefore, it appears that in the present situation, Bangladesh RMG industries will not be able to compete successfully in the international market due to the existence of unusually long lead time. Thus, this study focuses on investigating and analyzing the particular reasons which are responsible for the delay in target lead time in apparel supply chain and providing a prospective solution against them.

\section{Materials and Methods}

\subsection{Materials}

The study was carried out on a cold pigment dyed knit ladies fullsleeve t-shirt. Order of confirmation date from buying office was 05.03 .15 and the shipment date for full quantity was 30.7.15. The fabric used for making body portion of the garments was $100 \%$ cotton-single jersey having RFD gsm165 with yarn count of $\mathrm{Ne} 30 / 1$ (combed) and knitting gauge 28gg. For neck binding lycra (1X1 rib), fabric was used which was composed of $95 \%$ cotton and 5\% lycra having gsm 220. Spun polyester sewing thread was used for sewing. Among three styles, two had chest print with foil and the remaining style had neck print with front placket. Total order quantity was 73,890 pcs with the following color wise breakdown and SMV.

Table 1. Breakdown summary of total order

\begin{tabular}{|c|c|c|c|c|}
\hline Order No & Style & Color & Qty & SMV \\
\hline \multirow{3}{*}{3011} & A & Red & 24630 & $05.12 \mathrm{~min}$ \\
\cline { 2 - 5 } & B & Blue & 24630 & $10.45 \mathrm{~min}$ \\
\cline { 2 - 5 } & C & Grey & 24630 & $07.56 \mathrm{~min}$ \\
\hline
\end{tabular}

Style-A consists of foil print at the chest and back neck with shell fabric binding at the neck having raw edges. Style-B consists of placket with button at the front part having rib binding at the neck and sleeve opening. Style-C has foil print at the chest and label print with pigment at back neck. 


\subsection{Sampling Procedure}

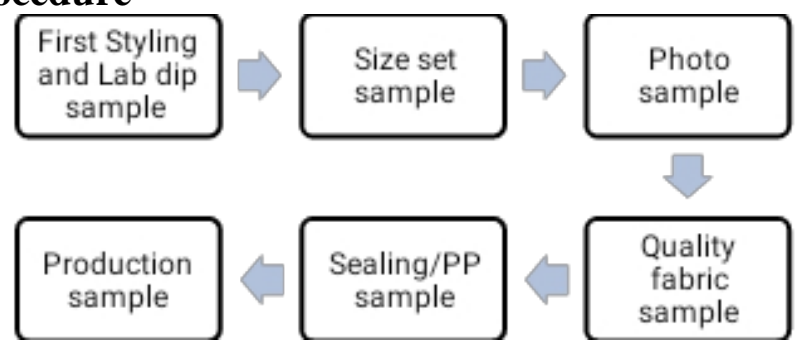

Figure 1. Sample hierarchy in sampling stage

\subsection{Production Procedure}

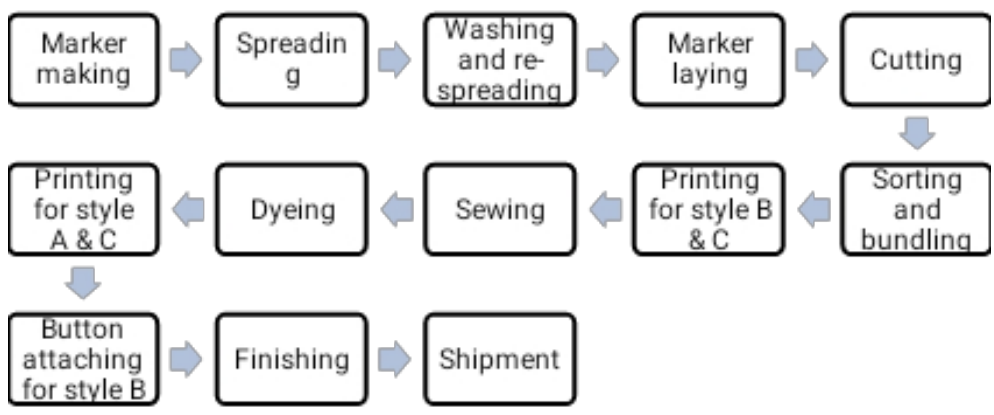

Figure 2. Production procedure followed during order execution

\subsection{Items Approval Procedure}

To secure approval or comments on an item from the ultimate buyer, the route below must be followed by the given buyer.

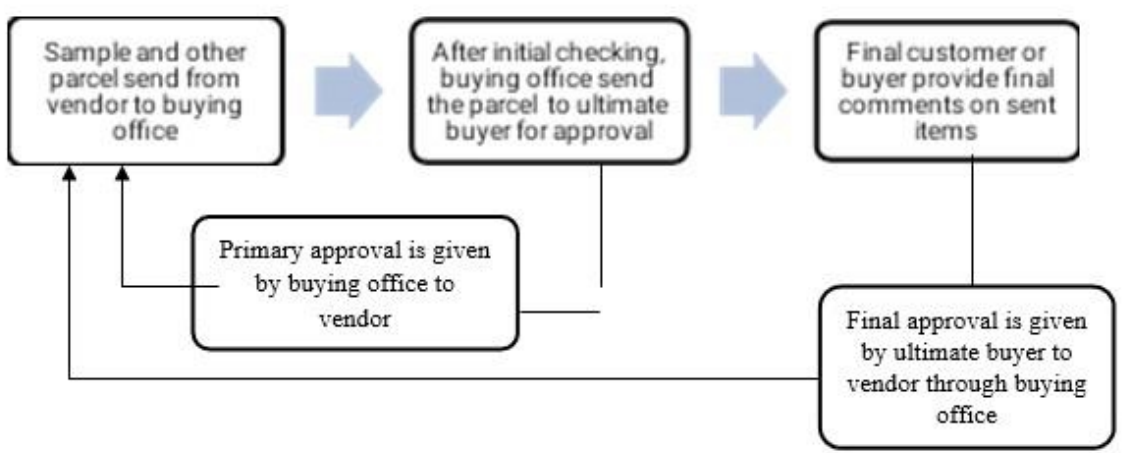

Figure 3. Sample approval procedure diagram 


\section{Results and Discussion}

\subsection{Delayed Approval Period}

Table 2. Time (days) required for different items

\begin{tabular}{|cccc|}
\hline Item Type & $\begin{array}{c}\text { Actual time (Days) } \\
\text { required from submission } \\
\text { to comments received }\end{array}$ & $\begin{array}{c}\text { Usual time } \\
\text { require } \\
\text { (Days) }\end{array}$ & $\begin{array}{c}\text { Delayed time } \\
\text { (Days) }\end{array}$ \\
Metal Button & $15\left(1^{\text {st }}\right.$ sub) & 9 & 6 \\
First styling & $17\left(2^{\text {nd }}\right.$ sub) & 9 & 8 \\
sample & 18 & 8 & 10 \\
Total Days & 50 & 26 & 24 \\
\hline
\end{tabular}

Table 2 represents the effect of approval period on lead time delaying issues. There are many causal factors for delayed approval period. The time required to convey the parcel to destination for approval is also a major issue in this case. For example, the selected buying office for this study is located in Europe. For this reason, it takes 3 days to convey items to buying office. Thereafter, it goes to the ultimate buyer for final approval. Time required to get approval is also dependent on item type and quantity. Usually, a larger volume of the parcel requires more time than shorter ones. Sometimes approval period may be delayed due to high work pressure from the buyer's side. However, in the abovementioned table, it is shown that in the case of metal button, the usual approval period is 9 days. However, it required 15 days to get approval. As a result of this, 6 days extension was needed here. In the case of first styling sample, the approval period needed was 18 days whereas the usual approval period is 8 days. As a result of this, it required 10 days' extra period. The metal button was sent twice as it was not approved in the first submission.

\subsection{Poor Quality Material and Re-work}

Table 3. Extra time (days) required for revised submission

\begin{tabular}{|c|c|c|c|c|}
\hline Item Type & $\begin{array}{l}\text { Actual time (Days) } \\
\text { required from } \\
\text { submission to } \\
\text { comments received }\end{array}$ & $\begin{array}{l}\text { Time (Days) } \\
\text { required up to } \\
\text { last submission }\end{array}$ & $\begin{array}{c}\text { Usual } \\
\text { Required } \\
\text { time (Days) }\end{array}$ & $\begin{array}{c}\text { Delayed } \\
\text { Period } \\
\text { (Days) }\end{array}$ \\
\hline $\begin{array}{c}\text { Print } \\
\text { strike-off }\end{array}$ & $\begin{array}{c}7\left(1^{\text {st }} \mathrm{sub}\right) \\
11\left(2^{\text {nd }} \mathrm{sub}\right) \\
7\left(3^{\text {rd }} \mathrm{sub}\right) \\
14\left(4^{\text {th }} \mathrm{sub}\right)\end{array}$ & 39 & 18 & 21 \\
\hline $\begin{array}{l}\text { Size set } \\
\text { sample }\end{array}$ & $\begin{array}{l}14\left(1^{\text {st }} \mathrm{sub}\right) \\
11\left(2^{\text {nd }} \mathrm{sub}\right)\end{array}$ & 25 & 14 & 11 \\
\hline $\begin{array}{l}\text { Lab dip } \\
\text { sample }\end{array}$ & $\begin{array}{l}10\left(1^{\text {st }} \mathrm{sub}\right) \\
11\left(2^{\text {nd }} \mathrm{sub}\right)\end{array}$ & 21 & 10 & 11 \\
\hline
\end{tabular}


Submission of a low quality material for approval may lead to resubmission. This happens when the quality of materials becomes poor. Sometimes vendors try to get approval by submitting items to buyers while ignoring its quality which also leads to re-submission or re-work. Practically, it is better to submit an item later than submitting poor quality goods earlier. There are many reasons for which poor quality items may be produced during production or order execution. For instance, poor skill can be one of them. In addition, lack of support from production units, poor quality raw materials, poor understanding about product details, miscommunication among interdepartments, frequent change in design or layout, etc., are further reasons for producing low quality items. Table 3 shows that during order execution, print strike-off made four submissions to get final approval. This means that it required a fourfold approval period. Normally, one or two submissions are required for this type of print approval. However, due to poor wash fastness of printed patterns and wrong color matching, it required a fourfold rework. Similarly, size set sample and lab dip sample did not get approval for the first time due to incorrect measurements and a wrong shade in the dyed sample. Nevertheless, buyers sometimes change the measurements, color, and demands for re-submission. Analyzing these three items, it can be easily said that re-submission and re-work lead to an extended lead time of 22 days for two samples and 21 days for print strike-off.

\subsection{Raw Material Supply and Shipment Date}

The order technical pack or specification sheet was received one month before sending the first styling sample. This means that around 30 days was required to in-house fabric, sewing thread, dyeing, and so on. Also, metal buttons were sent in the second time 45 days later for approval after getting 1st submission comments as it was imported from outside the country. This indicates that huge time was consumed to produce the first sample due to raw materials delay. Furthermore, the actual shipment date was July 20, 2015, but the achieved shipment date for total quantity was September 4, 2015, which is also 45 days extended period. Table 1 and Table 2 reflect that the extended shipment period is not equal to total delayed period. This is because several tasks take place simultaneously during order execution. For example, in the sampling stage, two different types, e.g., size set and photo sample were sometimes sent together for approval. In this case, failing in one category sample does not significantly delay lead time as later samples need to be prepared after getting comments of former sample. 


\subsection{Gantt Chart of the Order}

Table 4. Gantt chart of the executed order

\begin{tabular}{|c|c|c|c|c|c|c|c|c|c|c|c|c|c|c|c|c|c|c|c|c|c|c|c|c|c|c|c|c|c|}
\hline \multicolumn{30}{|c|}{ Gantt Chart } \\
\hline \multirow{2}{*}{ Activities } & \multirow{2}{*}{$\begin{array}{l}\text { Total } \\
\text { Days }\end{array}$} & \multicolumn{4}{|c|}{ Month-1 } & \multicolumn{4}{|c|}{ Month-2 } & \multicolumn{4}{|c|}{ Month-3 } & \multicolumn{4}{|c|}{ Month-4 } & \multicolumn{4}{|c|}{ Month-5 } & \multicolumn{4}{|c|}{ Month-6 } & \multicolumn{4}{|c|}{ Month-7 } \\
\hline & & 1 & 2 & 3 & 4 & 5 & 6 & 7 & 8 & 9 & 10 & 11 & 12 & 13 & 14 & 15 & 16 & 17 & 18 & 19 & 20 & 21 & 22 & 23 & 24 & 25 & 26 & 27 & 28 \\
\hline Spec Received & 1 & & & & & & & & & & & & & & & & & & & & & & & & & & & & \\
\hline Fabric sourcing & 31 & & & & & & & & & & & & & & & & & & & & & & & & & & & & \\
\hline Sample preparation & 10 & & & & & & & & & & & & & & & & & & & & & & & & & & & & \\
\hline Lab dip sample & 11 & & & & & & & & & & & & & & & & & & & & & & & & & & & & \\
\hline Styling sample & 19 & & & & & & & & & & & & & & & & & & & & & & & & & & & & \\
\hline Print strike-off & 39 & & & & & & & & & & & & & & & & & & & & & & & & & & & & \\
\hline Metal Button & 32 & & & & & & & & & & & & & & & & & & & & & & & & & & & & \\
\hline $\begin{array}{l}\text { Size set preparation and } \\
\text { parcel }\end{array}$ & 21 & & & & & & & & & & & & & & & & & & & & & & & & & & & & \\
\hline $\begin{array}{c}\text { Photo sample preparation } \\
\text { and parcel }\end{array}$ & 11 & & & & & & & & & & & & & & & & & & & & & & & & & & & & \\
\hline PP sample & 21 & & & & & & & & & & & & & & & & & & & & & & & & & & & & \\
\hline Original carton sample & 10 & & & & & & & & & & & & & & & & & & & & & & & & & & & & \\
\hline Shipment & 2 & & & & & & & & & & & & & & & & & & & & & & & & & & & & \\
\hline Total & 208 & & & & & & & & & & & & & & & & & & & & & & & & & & & & \\
\hline
\end{tabular}


The above mentioned Gantt chart reflects the total period (days) required for order execution along with activity break down. All the period mentioned here for a particular task is from parcel or sample submission to sample approval. Among all, some activities are performed in parallel way to each other in order to reduce time. From the table, it is noticeable that the total time required to execute the order was 208 days. It is also worthy to note that 31 days was required for sourcing the fabric which can be one of the major causes for lead time extension. Aside these, time required for print strike-off and metal button were also too long. However, among all of these, very few days were required for original carton sample approval from buyer after which shipment of the goods were done.

\section{Conclusion}

Since 2005, Bangladesh entered into the quota free market. Since its entry, Bangladeshi apparel sector faces competition from other competitors. After analysis, it has been found that among the reasons responsible for lead time delaying, approval period, poor quality material, re-work, and raw material supply are the most important factors. Due to these reasons, the final shipment date needed to extend by an extra 45 days which is equal to the total lead time to execute a small order. As a result of this, this sector is facing problems of long lead time, i.e., more than 120 days to execute a particular order.

\section{Acknowledgement}

The authors are thankful to the management of Unique Designers Ltd. for providing the facilities of this study.

\section{Conflict of interest}

There is no conflict of interest.

\section{References:}

1. Askin, R. G., \& Goldberg, J. B. (2002). Design and analysis of lean production system. John Wiley\&Sons. Inc., New York.

2. Bruce, M., \& Daly, L. (2011). Adding value: challenges for UK apparel supply chain management-a review. Production Planning \& Control, 22(3), 210-220.

3. Bruce, M., Daly, L., \& Towers, N. (2004). Lean or agile: a solution for supply chain management in the textiles and clothing industry? International journal of operations \& production management, 24(2), 151-170.

4. Cigolini, R., Cozzi, M., \& Perona, M. (2004). A new framework for supply chain management: conceptual model and empirical 
test. International Journal of Operations \& Production Management, 24(1), 7-41.

5. Gaither, N., \& Frazier, G. (1999). Production and operations management. Thomson South-Western.

6. Gaskill, L. R. (1992). Toward a model of retail product development: A case study analysis. Clothing and Textiles Research Journal, 10(4), 17-24.

7. Graham, G., \& Adewole, A. (2005). Developing a strategic framework for efficient and effective optimisation of information in the supply chains of the UK clothing manufacture industry. Supply chain management: An international Journal.

8. Haque, K. M. A., Hossain, M. M., Hossain, M. S. J., Islam, M. A., Hassan, M., Shamshuzzaman, M., \& Hossain, M. D. (2011). Performance Evaluation of Bangladeshi Apparel and Textile Supply Chain Network, A Case Study. Performance Evaluation, 1(1), 211-218.

9. Harrington, H. J. (1996). The complete benchmarking implementation guide: total benchmarking management. McGrawHill.

10. Hilletofth, P., \& Hilmola, O. P. (2008). Supply chain management in fashion and textile industry. International Journal of Services Sciences, 1(2), 127-147.

11. Hilmola, O. P., Hejazi, A., \& Ojala, L. (2005). Supply chain management research using case studies: a literature analysis. International Journal of Integrated Supply Management, 1(3), 294-311.

12. Islam, M. S., \& Liang, G. Q. (2012). Supply chain management on apparel order process: A case study in Bangladesh garment industry. Asian Journal of Business and Management Sciences, 2(8), 60-72.

13. Karlsson, C., \& Åhlström, P. (1996). Assessing changes towards lean production. International Journal of Operations \& Production Management, 16(2), 24-41.

14. Lee, Y., \& Kincade, D. H. (2003). US apparel manufacturers' company characteristic differences based on SCM activities. Journal of Fashion Marketing and Management: An International Journal, 7(1), 31-48.

15. Nuruzzaman, M. (2005). Development of readymade garment business (RMG) in the process of lead time reduction-a study on Bangladeshi readymade garment sector. Unpublished Master's Thesis, GBS, Gothenburg University, Sweden. 
16. Nuruzzaman, M. (2007). Developing export of RMG products in Bangladesh: Analysisng the lead time. Management Trends, 4(1), 1-9.

17. Palpacuer, F., Gibbon, P., \& Thomsen, L. (2005). New challenges for developing country suppliers in global clothing chains: A comparative European perspective. World development, 33(3), 409-430.

18. Perry, M., Sohal, A. S., \& Rumpf, P. (1999). Quick response supply chain alliances in the Australian textiles, clothing and footwear industry. International Journal of Production Economics, 62(1-2), 119-132.

19. Sohal, A. S., \& Egglestone, A. (1994). Lean production: experience among Australian organizations. International journal of operations \& production management, 14(11), 35-51. 